\title{
農村地域における土地所有圈域構造に関する研究 A STUDY ON THE STRUCTURE ABOUT THE SPHERE OF LAND POSSESSION IN RURAL REGION
}

\author{
藍澤 宏*, 山下 仁**, 楠本明宏*** \\ Hiroshi AIZAWA, Masashi YAMASHITA and Akihiro KUSUMOTO
}

\begin{abstract}
This paper analizes the structure about the sphere of land possession in rural region.
This study confirms the following.

1) Land possession form groups by each settlement. So settlement functions a foundamental sphere of spatial structure.

2) The sphere of land possession is stratified correspond to the sphere of society, settlement -hamlet -village. And the sphere of farmlands or house lots gathers within that of settlement. Also the sphere of rice fields or forest gathers within that of hamlet.

3) Land possession of rice fields relates with forming the connection of settlements.

4) Small scale land owners relate with forming the connection of settlements, too. And the distributional pattern of 1 and possession differs by the stratum of them.
\end{abstract}

Keywords: sphere of land possession, sphere of society. location. form of rural settlement, stratum of land possession 所有圏域, 社会領域, 立地条件, 集落形態, 所有規模階層

1.はじめに

(1) 背景と目的

農村地域における集落は、農業生産のための田畑・山 林等の農林地と、生活のための宅地・道路等を主要な構 成要素として成立している。この集落は、一定の土地す なわち地理的な領域と、家、すなわち社会的な領域を成 立要件とした農村における最小の地域単位として捉えら れるばかりでなく、用水、土地の管理・保全といった農 業生産における関係や生活面においても密接な関係を持 ち、1つの地域社会として成立している。また、それら の集落を重層的に組み込む形で存在している地域社会単 位としての「地区」や「旧村」においても、それぞれが 自治的領域として成立してきたという歴史的な背景があ る。

このような「集落」「地区」「旧村」といった農村の 自治的領域の構成は、各々の領域の地域管理や地域づく りに対する地域独自の役割を果たすと同時に、それらが
互いに段階的、重首的に連係しあって、全体として広域 的で有機的なシステムを形成している。

一方、計画的側面においてお、農村地域の計画主体は 計画能力をむった自治体、つまり、住民自身であるとい う観点に立つならば、自治体の行政区域を構成する各段 階を計画基礎単位地域として捉え、それの位置付けを行 なう必要がある。

すなわち、土地利用計画が農村地域の空間整備の基本 であると考えるとき、「集落」「地区」「旧村」の各地 域単位が最小の地域単位である集落を媒介にいかに構成 しているかという土地所有の圏域構造を明らかにするこ とが計画の重要な要件となる。

そこで、既往研究"では、集落単位にその立地特性や 農家の所有規模階層から、農村地域の土地利用内容の変 遷内容とその構造的特徴を明らかにしてきた。本研究で は、その地域的な単位を自治的領域として現在です機能 している集落、地区、旧村の各段階 ${ }^{2)}$ で捉え、土地所有
* 東京工業大学:文教施設矿究開発センター 教授・ 工博

** (社) 農村生活総合研究センター 研究員・工博 *** 鹿島コーポレーション
Prof., Research and Development Center for Educational Facilities, Tokyo Institute of Technology, Dr. Eng. Researcher, Rural Life Research Institute, Dr. Eng.

Engineer, Kajima Corporation 


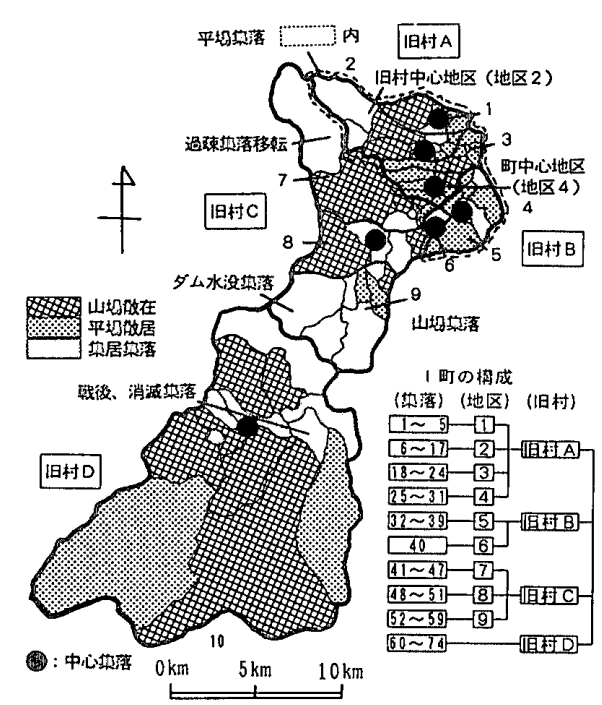

图 1

$Y$ 県।町の地域跡成と集落の立地条件

圈域と既存の地域社会の単位との対応から、(1)土地所有 階層毎の所有圈域の広狭の差異、(2)土地の地目每の所有 圈域の相違、(3)行政や農協等の公的な土地所有主体と私 的な土地所有主体との所有内容の相違、(4)平場集落や山 場集落等の集落立地の差から生じる土地種目内容とその 圈域構成の相違などを通じて、豐村地域の集落・地区・ 旧村などの計画単位としての意味付け、および計画単位 策定の基整的条件である構造的特徵を明らかにすること 目的としている。

\section{(2) 研究の方法}

研究の方法として、立地性の異なる集落・地区・旧村 の比較を通じて、次の分析を行なった。

2 節では、集落単位の土地所有率によって集落間の相 互関係を捉え、社会領域との対応を見る。それにょり、 集落の単位性と集落が群としてょり上位の社会領域に包 含される所有圈域の構成について明らかにする。

3 節では、所有規模（田と畑）による所有者の類型化 を行ない、所有規模階層ごとの所有圈域を求め、階層性 による所有圈域の相違と集落間の相互関係から、所有圈 域の構造を明らかにする。

4 節では、3 節までに明らかにした集落単位の所有圈 域構成と圈域構造について、町中心地区を事例に、事例 地区内の筆単位の分析を通じて、所有規模階層毎による 面的な所有地の分布の特徽と所有主体に上る所有圈域の 形成要件を明らかにする。

以上により土地所有圈域構成とその構造的特徵を求め ていった。そのために、研究の対象として、4旧村・10

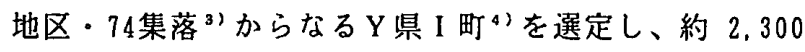

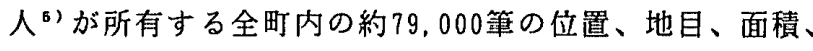
所有者、所有者の居住位置のデータを基に集計、分析を 行なった。なお、分析を行なう上で、次の 5 つの点につ いて留意した。
(1)土地の利用については、データに記載されている地 目種（田、㚼、宅地、池沼、山林、原野、雑種地、国鉄 用地 ${ }^{6)}$ 、学校用地、神社墓地など）によって捉え、2 節 以下では、特に田、畑、宅地、山林の 4 地目について、 地目別の所有圈域構成の特徵を捉えた。

(2)土地の所有者では、個人、団体”について、町内居 住者、町外居住者、公共（I 町、県、国）に分け、さら に町内居住者に対しては、居住位置を確定することによ り集落別に分穎した。また、3 節以下では、農地の所有 規模階層による所有圈域構成の違いを捉えるため、所有 者の田と畑の所有面積を基に、所有規模階層の分類を行 なった。

(3) 2 節、3 節では、集落単位に、集落内に居住する土 地所有者が、目集落・他集落に所有する割合を土地所有 率として概念を設定し、所有の広がりを捉えていった。 土地所有率の算定にあたっては、集落単位に菓落内居住 者の土地所有面積を寄せ集め、それぞれの土地が位置す る集落每に総所有面積に対する構成率を求めた。

(4)集落の立地条件として、中心地区 ${ }^{8)}$ 、中心集落・周 辺集落、平場 - 山場 ${ }^{9)}$ 、集居 - 平場散居 - 山場散在 ${ }^{10)}$ を設定し、それぞれの集落の位置づけを行なった。

(5) 4 節の事例地区の選定にあたっては、宅地が密集す る中心部から畨場内に散居状に宅地が点在する周辺部を 有し、様々な立地条件の集落が存在する現在の町中心地 区を事例として取り上げた。

（3）調查対象地域の概況

I 町を構成する歴史的に存在する地域構成単位は、集 落・地区・旧村等があり、その中で同じ郡部に属してい た 3つの旧村（旧村 A ・ B ・ C ）は、集落一地区一旧村 という形態とっている（図1）。しかし、これらとは別 の郡部に属していた旧村 Dは、ほぼ集落＝地区という形 態をとり、規模的には前者の集落とほぼ同等となってい る。これを前者の集落一地区一旧村という構成に当ては めて考えると、地区がなく、直接、集落から旧村という 構成になっていると考えることができる。また、これら の単位はそれぞれ、現在も行政施設、農業施設、教育施 設配置の地域単位として成立している。

ここで、対象集落・地区・旧村の位置づけを行なうた めに、基データを果落単位に土地所有主体別の土地利用 の構成率を表す14の变数に加工し、主成分分析により、 74 集落の穎型化を行なった（表 1）。14変数の内容は、 個人、企業 ${ }^{11}$ )、公共（I 町、県、国）の3つの所有主 体別の所有する、宅地（または建物用地）、農地（公共 と企業はなし）、山林の実面積と構成率である。

1 軸は個人の宅地率および個人の農地率がプラス側に 寄与を示し、マイナス側に山林率と山林規模が主として 寄与することから農地・宅地一山林軸と解釈され、同様 に2 軸は公共一企業軸と解橎される。この $1 、 2$ 軸の各 
表 1 所有主体別の土地利用構成率 14 変数の固有ベクトルと固有檤

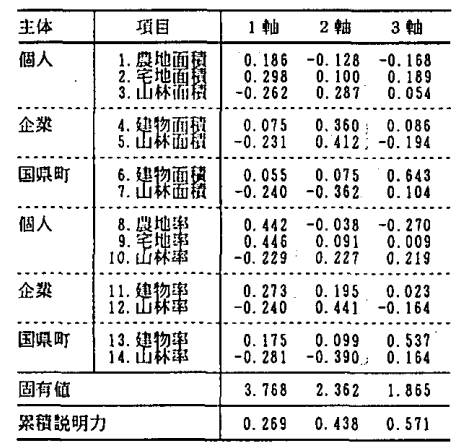
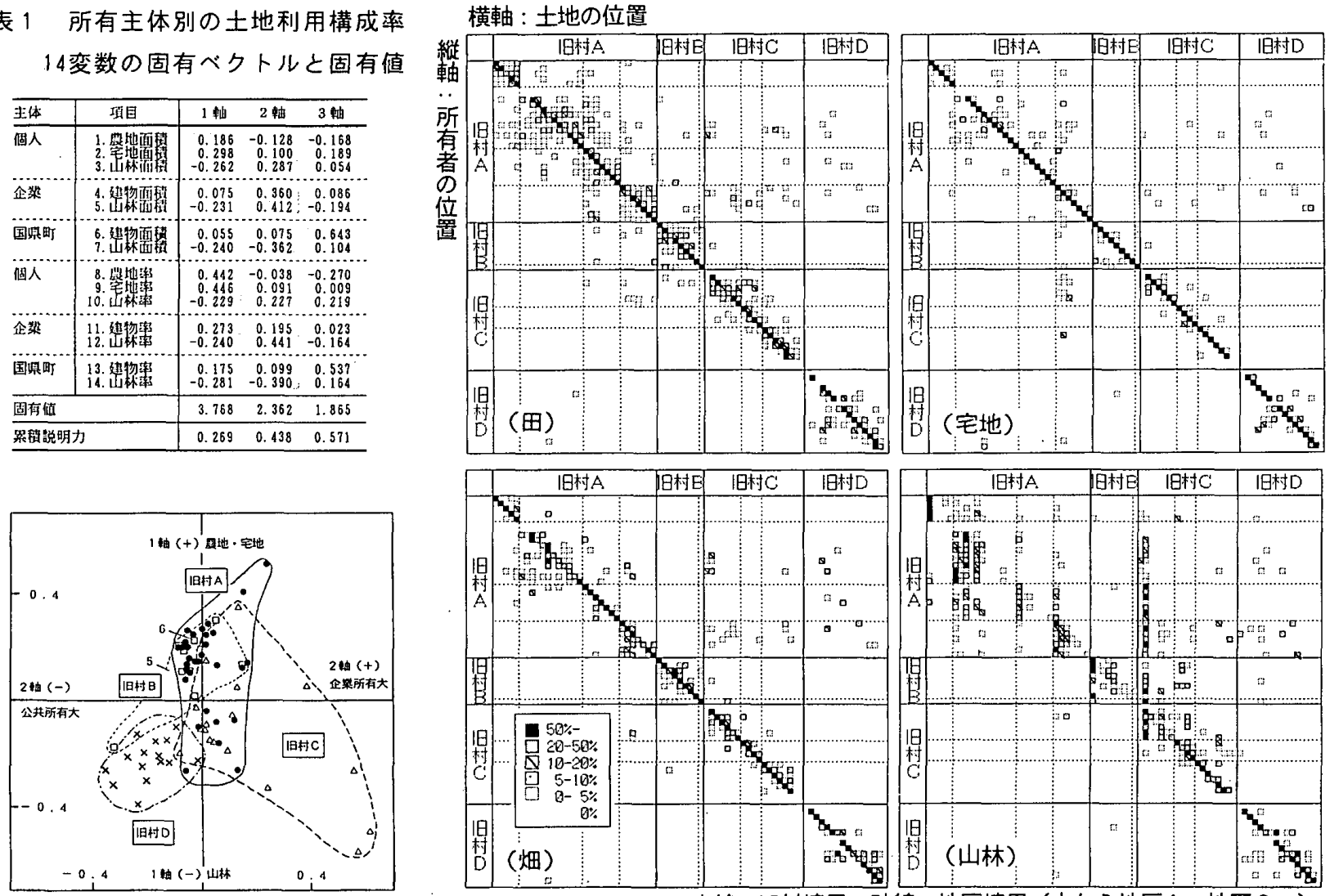

図274集落の分布 $(1-2$ 軸 $)$
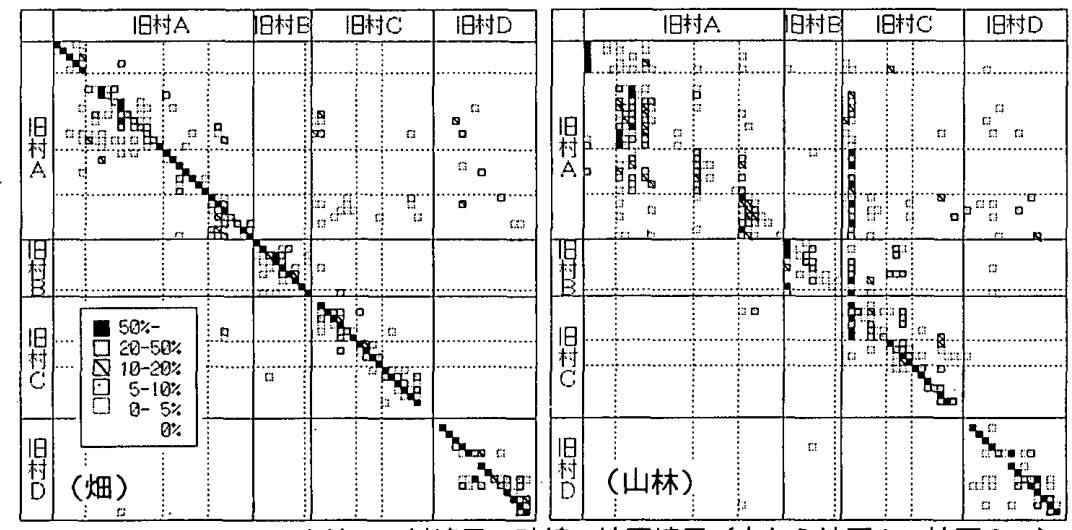

実線：旧村境界、破線：地区境界（上から地区 $1 、$ 地区 $2 \cdots$ ）

図了地目毎の集落属地の土地所有率マトリックス
集落の得点を基に 74 集落を 1 - 2 軸平面上にプロットし たすのが図 2 である。

各集落は、ほぼ旧村単位にまとまって分布しており、 旧村 A は個人農地 - 宅地型〜個人山林型、旧村 B は個人 宅地 ·農地型中心、旧村 C は個人農地・宅地型〜企業山 林型、旧村 D は公共山林型の集落が多い旧村としてそれ ぞれ位置づけられる。即ち、各集落の土地所有構成は旧 村毎に一定の共通する性格を有する。

\section{2. 集落間の土地所有率からみた所有圈域構成}

\section{(1) 土地所有率からみた集落間関連}

土地所有による集落間の関係を捉えるため、ある集落 内に居住する複数の土地所有者（個人）が、自集落・他 集落にどの程度の土地を持っているかという集落属地の 広がりについて、集落単位の土地所有率によるマトリッ クスを作成した（図3）。

集落每の土地所有率の算定にあたっては、研究の方法 で述べたように、基デー夕を居住集落ごとに寄せ集め、 どの集落に分布するか、その構成率を求めた ${ }^{12) 。 つ ま ~}$ り、図中では、各集落の居住者による所有について、横 軸の合計が $100 \%$ となっている。なお、図中における破 線は地区、実線は旧村の境界を表わすほか、集落は集落 番号順に並び、図中の上下あるいは隣り合う集落はほぼ 隣接関係にあると見なされる。
各地目ごとに所有の分布状況をみると、宅地は集落内 で完結する度合いが高く、所有の䡉囲は自集落を中心と し地区内の隣接集落においてほぼ収束する。また、畑は 自集落内における完結性は低くなるが、地区内の隣接集 落程度の所有が中心となり、地区外への広がりは少ない。

一方、田は宅地や畑よりも所有の範囲が広い。特に旧 村 C・旧村 B の平場集落では地区内の集落に所有率の大 きい範囲が広く分布し、その一部は隣接地区の集落まで 及んでいる。それに対して、山場集落では所有の範囲は 狭くなる。この平場と山場の所有形態の違いは、田は水 利の面で立地的制約があることや、地形上、平場では集 落が面的に配置されるのに対して、山場では集落が河川 流域に線状に配置されることによると考えられる。

また、山林についてみると ${ }^{13)}$ 、旧村 C ・ 旧村 B の各 々の地区において集落内の所有率が低く、地区内の特定 集落への依存がみられるようになるが、地区外の集落へ の広がりは見られずに地区内の所有の傾向が強い。また、 地区7 の特定の集落への所有が強く表れているが、これ は集落移転により平場集落へ居住者の集団的な移転が行 なわれたという経緯によるすのである。また山場が多い 旧村の旧村 C・旧村 Dでは、自集落内あるいは隣接集落 程度の距離に山林率の高い集落が存在するため、平場集 落に比べ、所有の広がりは小さくなり、自集落内あるい は隣接集落程度の所有範囲になる。 

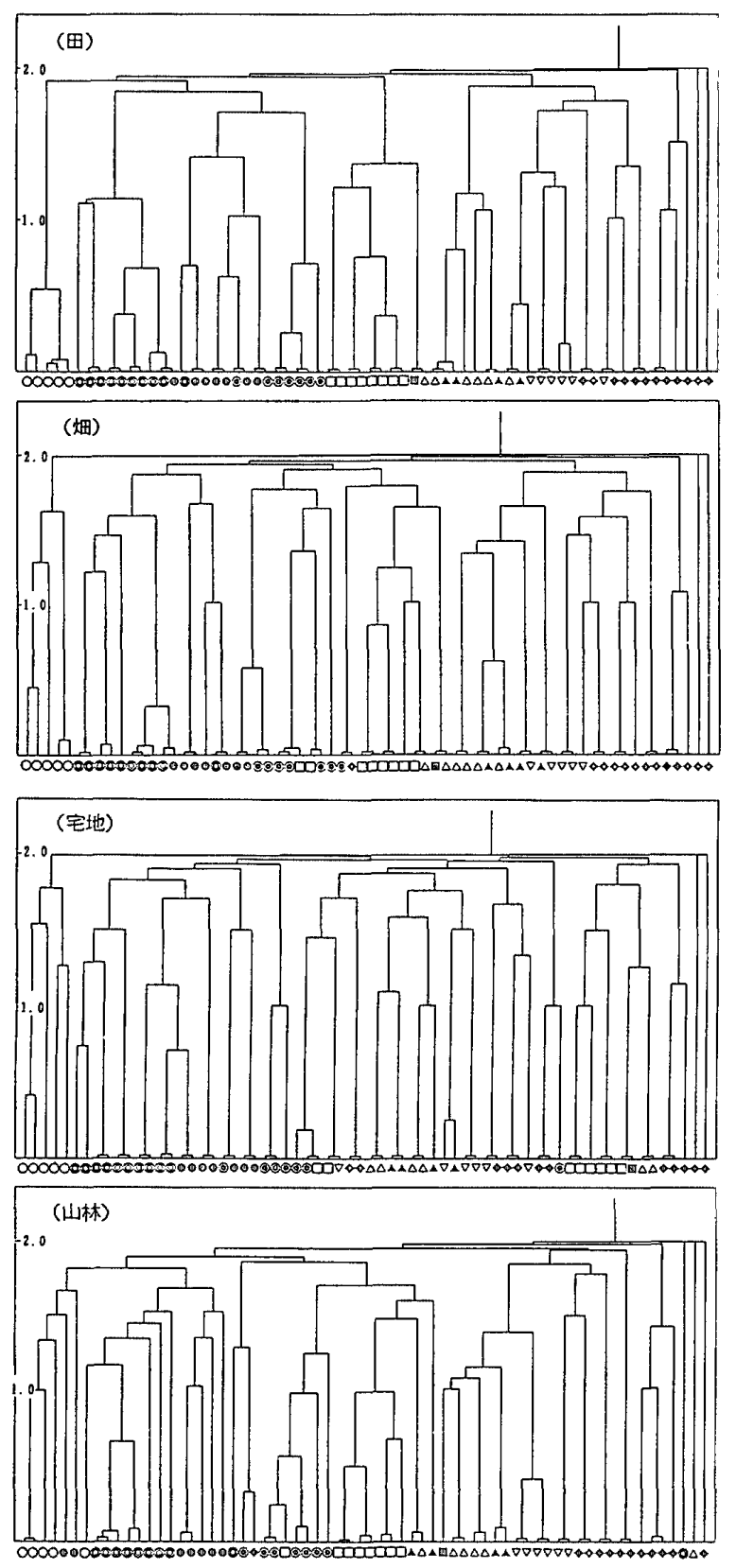

図 4 地目每の集落間土地所有率 クラスターによる樹形図

所有構造を地目間において比較すると、㚼、宅地につ いては田の所有圏域内に包含される構造を持つが、山林 では、これらと異なった構造を持っむのの地区内での完 結性は高い。すなわち、地域や地目により集落間の関連 度合いと土地所有圈域は異なるが、土地所有による空間 構造は集落を基礎領域として成立しており、䇟接集落か ら地区内集落までの範囲で一定の収束をみせ、その上限 を旧村として成立している。

（2）集落の群椿成と社会領域の対応

次に集落間の土地の所有関係から集落を群として捉え、 その群構成と社会領域の関係をみるために各集落の地目 ごとの土地所有率によりクラスター分析（群平均法）を
表 2 笨落立地条件別にみた集落属地の所有圈域棈成

\begin{tabular}{|c|c|c|c|c|c|c|c|}
\hline \multirow[b]{2}{*}{ 田 } & \multicolumn{3}{|c|}{ 地区内 } & \multicolumn{2}{|l|}{ 旧村内 } & \multicolumn{2}{|l|}{ 旧村外 } \\
\hline & 自集落 & 圂接 その他 & it & 选接 その他 & 叶 & 郴接 その他 & B十 \\
\hline $\begin{array}{c}\text { 中心地区 } \\
\text { その他 }\end{array}$ & 74. & $\begin{array}{ll}17.0 & 3.0 \\
16.4 & 4.0 \\
\end{array}$ & $\begin{array}{l}9 \\
1 \\
\end{array}$ & $\begin{array}{ll}4.6 & 1.2 \\
1.6 & 1.8 \\
\end{array}$ & $\begin{array}{l}5.7 \\
3.5 \\
\end{array}$ & \begin{tabular}{ll|}
1.1 & 5.4 \\
.2 & 1.2 \\
\end{tabular} & 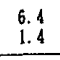 \\
\hline 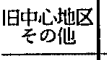 & $\begin{array}{l}66.2 \\
75.3 \\
\end{array}$ & \begin{tabular}{ll|}
13.6 & 7.8 \\
17.0 & 3.1 \\
\end{tabular} & 5 & $\begin{array}{ll}3.4 & 5.4 \\
1.7 & 1.1 \\
\end{array}$ & $\begin{array}{l}8.8 \\
2.8 \\
\end{array}$ & 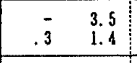 & $\begin{array}{l}3.5 \\
1.7 \\
\end{array}$ \\
\hline $\begin{array}{l}\text { 中心櫵䔔 } \\
\text { 楁 }\end{array}$ & $\begin{array}{l}52.0 \\
77.6 \\
\end{array}$ & $\begin{array}{|ll|}35.0 & 4.8 \\
13.4 & 3.7 \\
\end{array}$ & 91.8 & $\begin{array}{ll}2.2 & 2.5 \\
1.9 & 1.6 \\
\end{array}$ & $\begin{array}{l}4.6 \\
3.6 \\
\end{array}$ & $\begin{array}{rr}1.0 & 2.5 \\
.2 & 1.5 \\
\end{array}$ & $\begin{array}{l}3.6 \\
1.7\end{array}$ \\
\hline 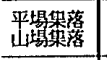 & $\begin{array}{l}72.0 \\
78.7 \\
\end{array}$ & $\begin{array}{|ll|}16.8 & 4.3 \\
15.7 & 2.8 \\
\end{array}$ & $\begin{array}{l}93.1 \\
97.3 \\
\end{array}$ & $\begin{array}{rr}2.2 & 2.3 \\
1.4 & .5 \\
\end{array}$ & $\begin{array}{l}4.5 \\
1.9 \\
\end{array}$ & $\begin{array}{rr}.4 & 2.1 \\
-\quad .8 \\
\end{array}$ & $\begin{array}{r}2.4 \\
.9 \\
\end{array}$ \\
\hline 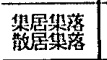 & $\begin{array}{ll}67.8 \\
76.7\end{array}$ & $\begin{array}{|ll|}21.4 & 5.0 \\
14.3 & 3.3 \\
\end{array}$ & $\begin{array}{l}94.2 \\
94.3 \\
\end{array}$ & $\begin{array}{ll}2.4 & 1.6 \\
1.8 & 1.8 \\
\end{array}$ & $\begin{array}{l}4.0 \\
3.6 \\
\end{array}$ & $\begin{array}{rr}.2 & 1.6 \\
.4 & 1.7 \\
\end{array}$ & $\begin{array}{l}1.8 \\
2.1 \\
\end{array}$ \\
\hline 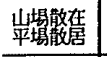 & $\begin{array}{l}81.9 \\
76.7 \\
\end{array}$ & $\begin{array}{rr}11.0 & 2.4 \\
13.0 & 4.0 \\
\end{array}$ & $\begin{array}{r}95.3 \\
93.7 \\
\end{array}$ & $\begin{array}{rr}2.7 & .8 \\
1.3 & 2.5 \\
\end{array}$ & $\begin{array}{l}3.5 \\
\text { 3. } 8 \\
\end{array}$ & $\begin{array}{ll}.1 & 1.1 \\
.5 & 2.0 \\
\end{array}$ & $\begin{array}{l}1.2 \\
2.5 \\
\end{array}$ \\
\hline 㚼 & 自架落 & 阥接 モの他 & st & 並接 その他 & 㔚 & 陆接 その他 & 㩆 \\
\hline $\begin{array}{l}\text { 中心地区 } \\
\text { そo他 }\end{array}$ & $\begin{array}{l}62.0 \\
76.1 \\
\end{array}$ & \begin{tabular}{rc|}
20.5 & 7.9 \\
11.9 & 6.5 \\
\end{tabular} & $\begin{array}{r}90.5 \\
94.5 \\
\end{array}$ & $\begin{array}{ll}.2 & 2 . \overline{4} \\
\end{array}$ & 2.2 & \begin{tabular}{ll|}
1.6 & 7.8 \\
.3 & 2.5 \\
\end{tabular} & $\begin{array}{l}9.4 \\
2.7 \\
\end{array}$ \\
\hline 他心批区 & $\begin{array}{l}50.9 \\
77.6\end{array}$ & $\begin{array}{rr}18.5 & 13.0 \\
12.3 & 5.8 \\
\end{array}$ & $\begin{array}{r}82.5 \\
95.6 \\
\end{array}$ & $\begin{array}{rr}.5 & 3.9 \\
.3 & 1.8 \\
\end{array}$ & $\begin{array}{l}4.5 \\
2.1 \\
\end{array}$ & \begin{tabular}{rr|r} 
& 13.0 \\
& 1.8 \\
\end{tabular} & $\begin{array}{r}13.0 \\
2.3 \\
\end{array}$ \\
\hline 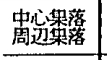 & $\begin{array}{r}71.2 \\
74.9 \\
\end{array}$ & \begin{tabular}{ll|}
13.7 & 6.7 \\
13.0 & 6.7 \\
\end{tabular} & $\begin{array}{l}91.6 \\
94.5 \\
\end{array}$ & $\begin{array}{rr}.4 & .3 \\
.3 & 2.5 \\
\end{array}$ & $\begin{array}{r}.7 \\
2.8 \\
\end{array}$ & $\begin{array}{rr}1.2 & 6.5 \\
.3 & 2.4 \\
\end{array}$ & $\begin{array}{l}7.7 \\
2.7 \\
\end{array}$ \\
\hline 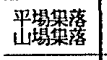 & $\begin{array}{l}70.7 \\
77.8 \\
\end{array}$ & \begin{tabular}{ll|}
14.5 & 6.1 \\
11.7 & 7.3 \\
\end{tabular} & $\begin{array}{l}91.2 \\
96.8\end{array}$ & $\begin{array}{ll}.3 & 1.8 \\
.2 & 2.4 \\
\end{array}$ & $\begin{array}{l}2.1 \\
2.6 \\
\end{array}$ & $\begin{array}{rr}.4 & 6.2 \\
.4 & .2 \\
\end{array}$ & $\begin{array}{r}6.6 \\
.6 \\
\end{array}$ \\
\hline 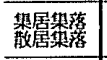 & $\begin{array}{l}71.2 \\
75.9 \\
\end{array}$ & \begin{tabular}{ll|}
10.2 & 9.9 \\
14.7 & 4.9 \\
\end{tabular} & 91.2 & $\begin{array}{ll}.6 & 4.0 \\
.1 & 1.0 \\
\end{array}$ & 1.1 & $\begin{array}{ll}.7 & 4.2 \\
.7 & 2.7 \\
\end{array}$ & $\begin{array}{r}4.2 \\
3.4 \\
\end{array}$ \\
\hline 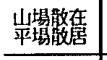 & $\begin{array}{l}77.9 \\
74.3 \\
\end{array}$ & \begin{tabular}{ll|}
17.5 & 3.0 \\
12.9 & 5.8 \\
\end{tabular} & $\begin{array}{l}98.4 \\
93.0 \\
\end{array}$ & $.2 \quad .4$ & $\begin{array}{r}.6 \\
1.6 \\
\end{array}$ & \begin{tabular}{rr|}
.9 & 4.7 \\
\end{tabular} & $\begin{array}{l}1.0 \\
5.4 \\
\end{array}$ \\
\hline 宅地 & 自㷛落 & 䧄接 その他 & st & 隣接 その他 & 㔚 & 姚接 その他 & $8+$ \\
\hline $\begin{array}{l}\text { 中心地区 } \\
\text { 它の他 }\end{array}$ & & $\begin{array}{ll}3.8 & 1.4 \\
2.7 & 2.0 \\
\end{array}$ & $\begin{array}{l}96.2 \\
97.2 \\
\end{array}$ & $.5 \quad 1.1$ & 1.6 & $\begin{array}{ll:}.4 & 3.1 \\
.3 & 1.0 \\
\end{array}$ & $\begin{array}{l}3.5 \\
1.3 \\
\end{array}$ \\
\hline $\begin{array}{c}\text { 日中心地区 } \\
\text { その他 } \\
\end{array}$ & $\begin{array}{l}87.8 \\
93.3 \\
\end{array}$ & \begin{tabular}{ll|}
4.4 & 3.4 \\
2.5 & 1.5 \\
\end{tabular} & $\begin{array}{r}95.6 \\
97.4 \\
\end{array}$ & $\begin{array}{rr}.1 & 2.8 \\
.5 & .5 \\
\end{array}$ & $\begin{array}{l}2.9 \\
1.0 .\end{array}$ & \begin{tabular}{ll|} 
& 1.5 \\
& 1.2 \\
\end{tabular} & $\begin{array}{l}1.5 \\
1.6 \\
\end{array}$ \\
\hline 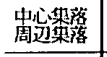 & 92.7 & $\begin{array}{ll}4.0 & 2.1 \\
2.6 & 1.8 \\
\end{array}$ & $\begin{array}{l}96.7 \\
97.1 \\
\end{array}$ & $\begin{array}{rr}. \overline{6} & 1.1 \\
\end{array}$ & $\begin{array}{l}1.1 \\
1.5 \\
\end{array}$ & \begin{tabular}{ll|}
.3 & 2.0 \\
.3 & 1.1 \\
\end{tabular} & $\begin{array}{l}2.2 \\
1.4 \\
\end{array}$ \\
\hline 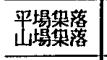 & $\begin{array}{l}92.2 \\
92.4 \\
\end{array}$ & \begin{tabular}{ll|}
2.8 & 1.8 \\
3.1 & 1.9 \\
\end{tabular} & $\begin{array}{l}96.8 \\
97.4 \\
\end{array}$ & $\begin{array}{rr}.6 & 1.2 \\
.2 & .3 \\
\end{array}$ & $\begin{array}{r}1.8 \\
.4 \\
\end{array}$ & $\begin{array}{ll}.1 & 1.3 \\
.8 & 1.4 \\
\end{array}$ & $\begin{array}{l}1.4 \\
2.2 \\
\end{array}$ \\
\hline 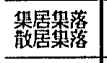 & $\begin{array}{l}92.6 \\
92.0 \\
\end{array}$ & $\begin{array}{ll}3.0 & 2.0 \\
2.8 & 1.8 \\
\end{array}$ & $\begin{array}{l}97.6 \\
96.7 \\
\end{array}$ & $\begin{array}{rr}.1 & 1.2 \\
.6 & .8 \\
\end{array}$ & $\begin{array}{l}1.3 \\
1.4 \\
\end{array}$ & $\begin{array}{ll}.5 & 1.1 \\
.5 & 1.4 \\
\end{array}$ & $\begin{array}{l}1.1 \\
1.9 \\
\end{array}$ \\
\hline 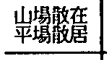 & $\begin{array}{l}93.4 \\
91.8 \\
\end{array}$ & $\begin{array}{ll}1.7 & 1.9 \\
3.2 & 1.8 \\
\end{array}$ & $\begin{array}{r}96.9 \\
96.8 \\
\end{array}$ & $\begin{array}{rr}1 & .7 \\
.9 & 1.0 \\
\end{array}$ & $\begin{array}{r}.8 \\
1.9 \\
\end{array}$ & \begin{tabular}{ll|}
1.1 & 1.2 \\
.1 & 1.2 \\
\end{tabular} & $\begin{array}{l}2.3 \\
1.4 \\
\end{array}$ \\
\hline 山林 & 自集落 & 辢接 その他 & at & 慥接 その他 & à & 陵接 その他 & 踇 \\
\hline 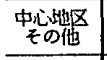 & $\begin{array}{r}15.8 \\
37.6 \\
\end{array}$ & $\begin{array}{ll}13.0 & 19.2 \\
22.3 & 20.2 \\
\end{array}$ & $\begin{array}{l}48.1 \\
80.1\end{array}$ & $\begin{array}{rr}.1 & 2.4 \\
2.5 & 6.2 \\
\end{array}$ & $\begin{array}{l}2.6 \\
8.7 \\
\end{array}$ & $\begin{array}{rr}8.8 & 40.6 \\
.6 & 10.6 \\
\end{array}$ & 1 \\
\hline 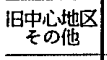 & $\begin{array}{r}7.6 \\
40.6 \\
\end{array}$ & $\begin{array}{ll}19.5 & 59.8 \\
21.4 & 11.3 \\
\end{array}$ & $\begin{array}{l}86.9 \\
73.3 \\
\end{array}$ & \begin{tabular}{ll|}
.4 & 1.5 \\
2.6 & 6.6 \\
\end{tabular} & 9.2 & $\begin{array}{ll}-\overline{1} & 11.2 \\
2.1 & 15.4 \\
\end{array}$ & 117.2 \\
\hline $\begin{array}{l}\text { 蛹边㣟落 } \\
\end{array}$ & $\begin{array}{r}25.9 \\
36.5 \\
\end{array}$ & $\begin{array}{rr}28.5 & 6.9 \\
19.3 & 23.2 \\
\end{array}$ & $\begin{array}{r}62.2 \\
78.9 \\
\end{array}$ & $\begin{array}{ll}3.7 & 2.5 \\
1.8 & 6.5 \\
\end{array}$ & $\begin{array}{l}6.2 \\
8.3 \\
\end{array}$ & \begin{tabular}{rr|}
6.2 & 25.3 \\
.7 & 12.2 \\
\end{tabular} & $\begin{array}{l}31.5 \\
12.8 \\
\end{array}$ \\
\hline 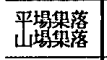 & $\begin{array}{l}12.1 \\
60.6\end{array}$ & $\begin{array}{rr}19.1 & 31.0 \\
23.2 & 7.4 \\
\end{array}$ & $\begin{array}{r}62.3 \\
91.2 \\
\end{array}$ & \begin{tabular}{ll|}
1.1 & 7.0 \\
3.4 & 4.2 \\
\end{tabular} & 7.7 & $\begin{array}{rr}3.2 & 26.4 \\
-\quad 1.2 \\
\end{array}$ & $\begin{array}{r}29.6 \\
1.2 \\
\end{array}$ \\
\hline 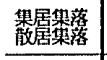 & $\begin{array}{r}28.0 \\
38.5 \\
\end{array}$ & \begin{tabular}{ll|}
35.0 & 14.3 \\
13.1 & 23.3 \\
\end{tabular} & 74. 9 & $\begin{array}{rr}5.6 & 3.0 \\
.3 & 7.2 \\
\end{array}$ & $\begin{array}{l}8.6 \\
7.5 \\
\end{array}$ & $\begin{array}{|ll|}2.7 & 14.2 \\
\end{array}$ & $\begin{array}{l}14.2 \\
17.7\end{array}$ \\
\hline 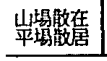 & $\begin{array}{l}60.0 \\
20.4 \\
\end{array}$ & $\begin{array}{ll}11.6 & 15.5 \\
14.0 & 32.3 \\
\end{array}$ & $\begin{array}{l}87.0 \\
66.8 \\
\end{array}$ & $\begin{array}{rr}3 & 4.7 \\
.2 & 9.6 \\
\end{array}$ & $\begin{array}{l}5.0 \\
9.8 \\
\end{array}$ & $\begin{array}{rr}5 . \overline{8} & 77.9 \\
\end{array}$ & $\begin{array}{r}7.9 \\
23.5\end{array}$ \\
\hline
\end{tabular}

行ない集落関連を求める（図 4）。一般に、クラスター 分析の対象となる個体の距離の定義として、数学的に定 義される空間上の距離または䝷似度が考えられるが、こ こでは、所有率が大きいほど個体 (集落) 間の距離が近 いと考え、2 集落間の所有率の相加平均の逆数によって 距離を定義した ${ }^{14)}$ 。なお、図において、集落の結びっ きの高さ（クラスター距離）は、低いほど集落間の所有 関係が強いことを表し、下に並んだ地区の記号は、まと まりがあるほど地区内の所有の完結性が高いことを表し ている。

はじめに、田についてみると、旧村 A ・旧村 Bでは、 まず地区内の 2 つから 3 つの集落が結合し、クラスター 距離 $0.5 \sim 1.5^{15)}$ で地区内の集落を包含するょうに統 合されて、ほぼ最大の距離 2.0で旧村が地区のクラスタ 一を含む構造をとる。それに対し、旧村 C・旧村Dでは、 
独立性の高い集落が存在するととすに、地区内で結合し て旧村でまとまるといった関係は薄れる。これは、集落 自体の独立性が高いこと、また、隣接集落まででその関 係がほぼ完結するためである。

畑や宅地についてす、各集落は、まず地区内の集落に よりクラスターが構成され、続いて地区内の集落が統合 するという構造をとるが、最初の結合では、隣接集落の レベルで、クラスター距離は小さく、関係が強いことが わかる。しかし、次の集落あるいは集落群との結合まで の距離は長くなり、地区としてのまとまりを得るのはク ラスター距離 1.5 以上と大きくなる。すなわち、各集落 は隣接集落程度のレベルでは所有関係をすつが、それ以 上の地区や旧村レベルでの関係は希薄となり、所有圈域 が狭く、集落間の独立性が強いことが示される。

山林では旧村 A ・旧村 B は地区内における山林率の高 い集落を核として地区内集落を順次取り込むかたちでク ラスターが構成され、さらに地区ا旧村へとまとまりを みせる。また、旧村 C・旧村 Dでは、自集落内あるいは 隣接集落程度の範囲で山林を所有するため集落の独立性 は高く、集落間の関係においても群としてのまとまりは 小さい。したがって、地区、旧村としてのまとまりを得 るまでのクラスター距離が大きく、地区レべルと旧村レ ベルのまとまりの関係では差がないものとなっている。

以上により、旧村 A ・旧村 B といった平場が多い旧村 では、互いに集落間の関係が強く、連担した形態をもっ ており、地区・旧村といった社会領域に順次包含されて いく構造がみられるが、山場の旧村 C・旧村 D では、集 落の独立性が高く、隣接する $2 \sim 3$ 集落における関係は 強いものの、複数の集落が面的に関係する度合いは小さ く、地区と旧村における結合は、ほぼ等しくなることが 示された。

\section{（3）集落立地条件之所有圈域との対応}

集落の社会的立地（中心・周辺）、地理的立地（平場 ・山場）、および集落形態（集居・散居）等の集落のそ れぞれの立地条件が、所有圈域構成にどんな関わりをも つか、すなわち、集落個別条件が所有圈域構成に影響を 与えているか否かについてみていく。地目每の集落立地 条件別にみた土地所有圈域構成を表 2 に示す（立地条件 に対する集落の位置については、図1を参照）。

田についてみると、中心集落、中心地区、および旧中

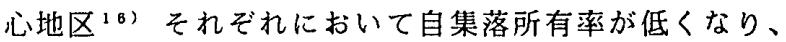
中心部から周辺部への所有の進出がみられる。ここで、 中心地区や旧中心地区については、それらの地区内に中 心集落之周辺集落が包括され、平均された結果、自集落 における所有率は高めにでている。それに対し、中心集 落之周辺集落の比較では、中心集落の自集落所有率が約 $50 \%$ 之低く、その分、隣接関係のある周辺集落へ所有が あらわれる。また、平場・山場別では、平場集落におい
て自集落所有率が低くなる。これは、前に述べたように、 水利の面での制約と、平場・山場での集落の分布形態が 異なることによるものである。

集居・散居別でみると、集居集落では自集落所有率が 低く、地区内の隣接集落あるいは地区内の他の集落への 所有の進出傾向が強くなる。これは、集居集落では宅地 周囲にまとまって農地を所有することが困難であるのに 比べて、散居集落では宅地を農地が取り囲むという形態 上、宅地周囲にまとまって農地を所有することが可能て あるといった違いによるるのである。

㚼についてみると、田と同様の傾向を示し、中心・旧 中心地区、中心集落、平場集落、集居集落において自集 落所有率が小さく、地区内の他の集落への所有傾向があ らわれる。しかし、㚼は田にくらへて、地理的立地条件 に左右される面が小さいため、その差は田に比べて小さ くなる傾向がある。一方、宅地についてみると、それぞ れ、自集落内での所有が約 $90 \%$ 程度と高く、中心・旧中 心地区、中心集落での自集落所有率が若干低くなり、周 辺集落の所有率が高くなる。また、山林については、田 ・㚼・宅地とは全く異なった所有形態を示すことがわか る。すなわち、平場集落で、自集落所有率が低く、山場 集落では大きくなる。しかしながら、第 1 節で述べたよ うに、山場集落から平場集落への居住者が移転した経緯 を考えると、地区内の集落までで所有率が約 $60 \%$ 程度に なることは、地区内で所有が完結しているといってもよ い。

以上により、各地目とも集落の社会的・地理的立地条 件・集落形態により所有形態は異なるが、全体として地 区内で所有が完結する傾向が示された。

\section{3.土地所有者の所有規模階層の相違からみた所有圈域 構造}

（1）所有規模階層の相違からみた集落間土地所有率

土地所有による集落間の圈域構造がどのような所有者 により形成されているのかを明らかにするため、土地所 有者の田と畑の所有規模により小規模（1 ha未満）・中 規模（（～～ 2 ha）・大規模（2 ha以上）の 3 つの階層に 分類し、その違いをみる。そこで、2節と同様に基デー 夕を居住集落每に所有規模別に加工することにより、集 落間の土地所有率を求めた ${ }^{71}$ 。地目每の所有規模階層 別による集落間土地所有率マトリックスを图 5 に示す。

田についてみると、小規模所有者と大規模所有者の場 合では、自集落と隣接集落を中心に地区の範团内に主に 分布する。そ机に対し、中規模所有者の場合は、自集落 の所有率が低くなり、変化した分が地区内に広がり、一 部が旧村内に分布するようになる。このことは特に平場 地区の中心集落で顕著となっている。

一方、畑では、全般的にどの階層す自集落と隣接集落 
横朝 : 土地の位置
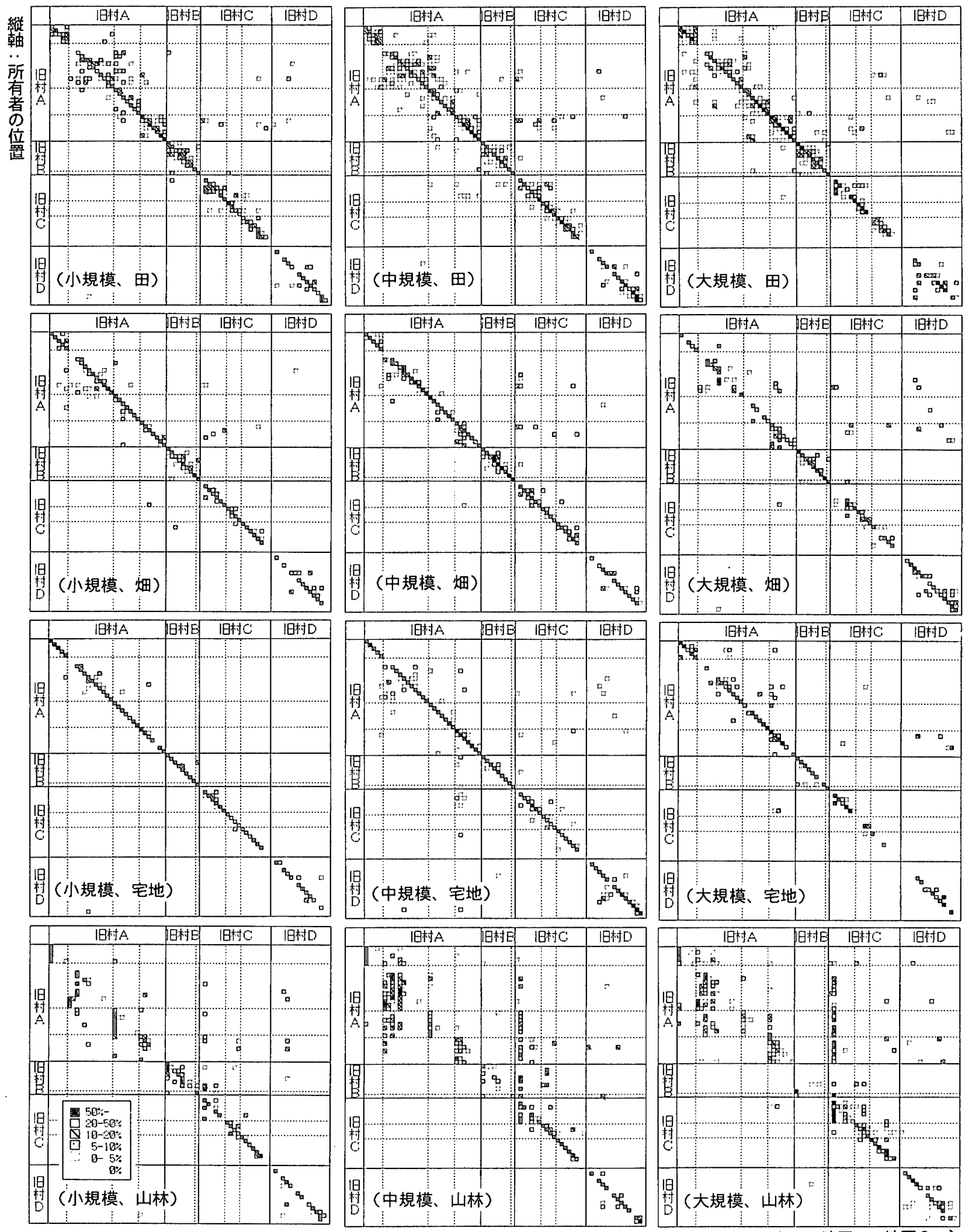

図 5 地目毎の所有規模階層別の土地所有率マトリックス

実線：旧村境界、破線：地区境界（上から地区 $1 、$ 地区 $2 \cdots$ ）

の所有率が高く、田に比べ分散が小さい。しかし、特に 大規模所有者の場合、自集落ではない特定の集落に分布 することがある。これは、畑地利用が多い集落に主にみ られ、これらの大規模所有者が集団的に畑を所有してい
ることを表している。

また、宅地についてみると、畑と同様に自集落の所有 率が高くなっているが、中規模所有者の場合について、 中心および旧中心地区の中心集落に一部の宅地を所有す 


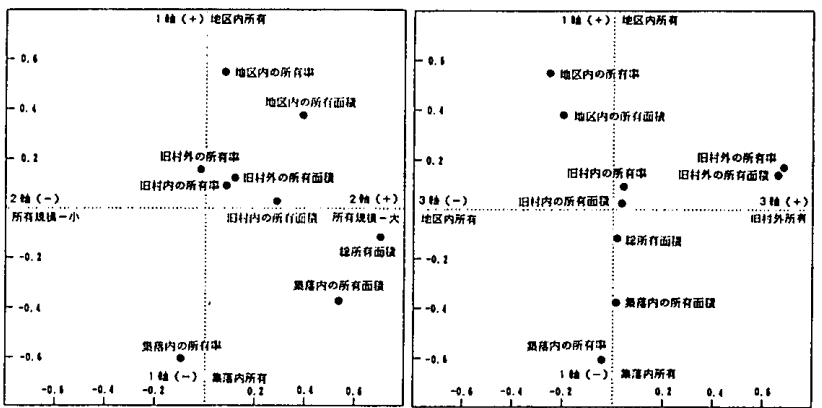

図 6 所有圈域別の所有面積・所有率 9 变数の

固有ベクトル（田）
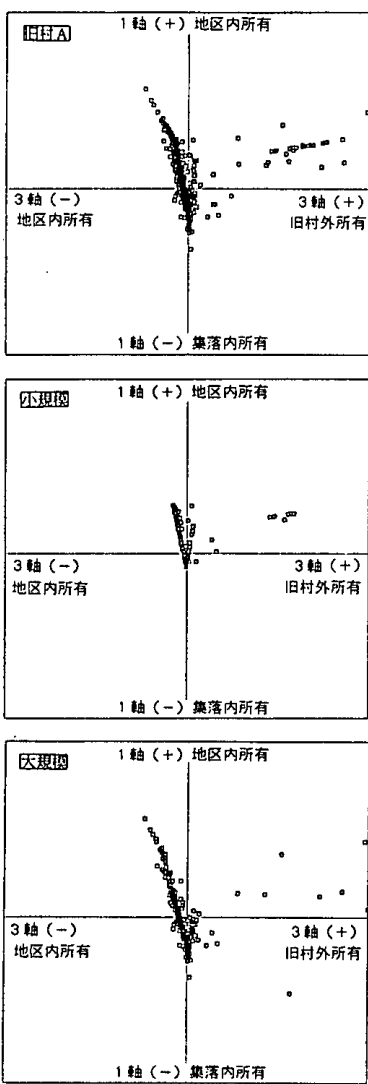

図 7 土地所有者の分布（田、1-3 軸）

る傾向がみられる。これは、大規模所有者が目集落内に まとまった宅地を所有するのに対し、中規模所有者の場 合は自集落の宅地所有規模が大規模所有者と比べて小さ く、宅地を別に持っ所有者が多いためと考えられる。

さらに、山林についてみると、どの階層です第 2 節で みたように山林が多い特定の集落への分布の集中がみら れるが、大規模所有者の場合に一層、顕著に表れている。 しかし、この場合でも、その特定の集落との関係を除け ば旧村という上限が存在していることが確認できる。

以上のことから、土地所有者の所有規模階層と集落間 土地所有率との関係として、どの所有規模階層の場合で も自集落・隣接集落を中心とする地区内所有という単位 が第一に存在し、その上限が旧村の範囲であり、これら の社会単位が土地利用の計画単位としても有効であるこ と、また、中規模土地所有者（1２ha）の場合に自集

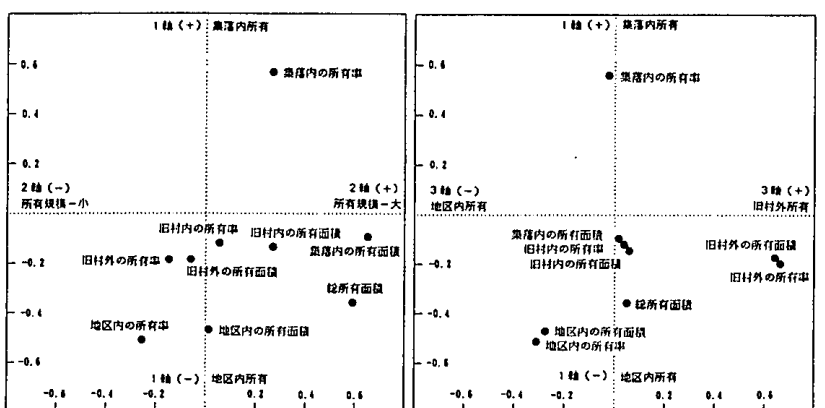

図 8 所有圈域別の所有面積・所有率 9 变数の 固有ベクトル（畑）
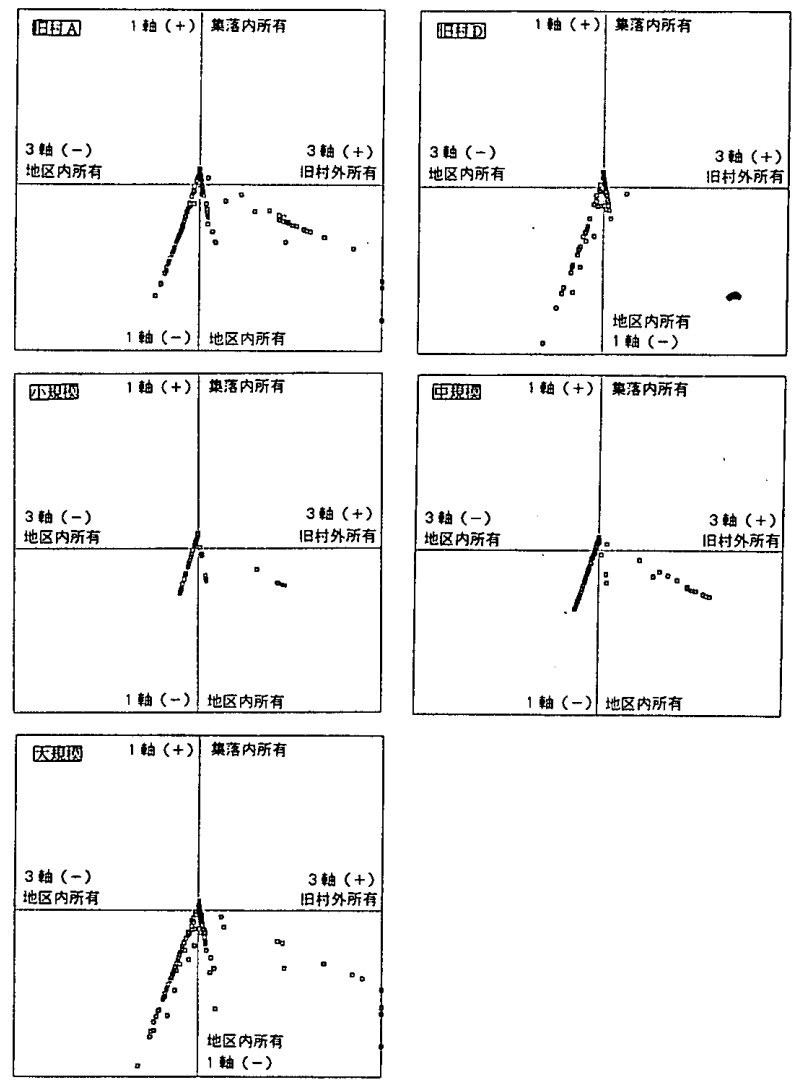

図 9 土地所有者の分布 (畑、1 - 3 軸)

落・隣接集落の所有率が低くなる分、所有の分布範囲が 広がることが示された。

（2）所有規模階層の相違からみた土地所有の圈域構造

土地所有者の所有構造を明らかにするために、田と㚼 の地目について、所有の分布内容を、自集落所有・地区 内集落所有（自集落を除く）・旧村内集落所有（地区内 を除く）・旧村外所有の 4 つに区分し、その所有面積と

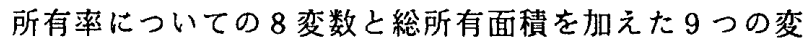
数によって基データを所有者単位に加工し、それを基に 主成分分析を行なった。

はじめに、田についてみる。1 軸から 3 軸までの固有 值は、それぞれ 2.4992、2.0243、1.7455 であり、累積 説明力は約70\%である（図 6)。各軸の解釈では、1 軸 は地区内面積、地区内所有率がプラス側で寄与を示し、 マイナス側においては集落内所有面積、集落内所有率が 
寄与することより、「地区内所有」一「集落内所有」軸 と意味付けられる。同様に、2 軸は、プラス側に総所有 面積が寄与する「規模」軸、3軸は、プラス側に旧村外 所有面積・所有率が寄与し、マイナス侧に地区内所有面 積・所有率が寄与する「地区内所有一旧村外所有」軸之 意味付けられる。なお、所有規模階層による相違をみる ために、「規模」軸を表わしている第 2 軸の検討はここ では省略し、第 1 軸之第 3 軸によってサンプル分布の特 徵をみていくことにした。

旧村ごとの比較では、平場の旧村 A ・旧村 B に比べ、 山場の旧村 C・旧村 Dにおいては炛落内所有の傾向が強 くなる(図 7)。特に山場の旧村 Dにおいては旧村外所 有が小さく、平場旧村と山場旧村における所有圈域の違 いが表れている。

所有規模階層ごとのプロットをみると、小規模層の所 有者は集落内所有傾向が強く、地区内所有の軸への分布 も少ない。中規模層においては、1 軸の集落内所有から 地区内所有の分布が一様に表れるのに対し、3軸のプラ 又側に旧村外所有の大きな所有者が表れる。大規模層で は、地区内所有の大きな所有者が多いが、旧村外所有㑯 向は小さく、集落内所有の方化分布が偏る。即ち、中規 模層の所有者において、所有圈域の大きなものがあらわ れ、大規模所有者については、集落内に大面積を所有す る傾向がみられる。

一方、畑では、3 軸までの固有值はそれぞれ 2.46683、 $1.9249 、 1.6533$ であり、累積説明力は $67 \%$ ある。各軸 の解积では、1 軸はプラス側に集落内所有率、マイナス 側に地区内所有面積と地区内所有率が寄与する「集落内 所有率」一「地区内所有」軸と解积できる(図 8)。同 様に 2 軸はプラス側に総所有規模などが寄与する「規模」 軸、3 軸はプラス側に旧村外所有面稓之旧村外所有率、 マイナス側に地区内所有面積と地区内所有率が寄与する 「地区内所有」一「旧村外所有」軸とそれぞれ意味付け られる。ここでは、田の場合と同様の理由により、13軸をみていくことにする。

旧村別のプロットをみると、平場中心地区が含まれる 旧村 Aでは、旧村外への所有が大きいものが分布する傾 向がみられるが、他の 3 旧村に関してはそれらの分布は 小さい（図 9）。また、山場旧村の旧村 C、旧村 Dでは 所有規模の大きい方に分布が広がるが、それらについて あ旧村外への分布にはならず、旧村内や地区内に収镆す ることが示される。また、平場集落が多い旧村 Bでは、 1 軸のマイナス側の分布が減少することから集落内所有 率が高いことがわかる。

所有規模階層別の分布をみると、小規模所有者・中規 模所有者は、ほぼ同様の分布をみせるが、大規模所有者 に関しては集落内所有率が小さくなり、旧村外所有に分 布の一部が現れるようになる。すなわち、小規模所有者

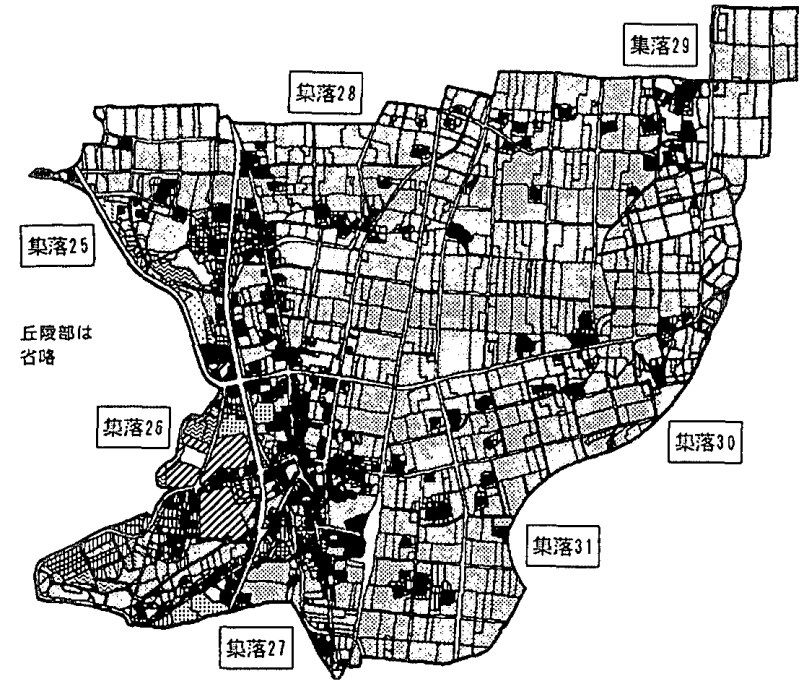

図10 町中心地区（地区 4) の土地利用現況（S63）
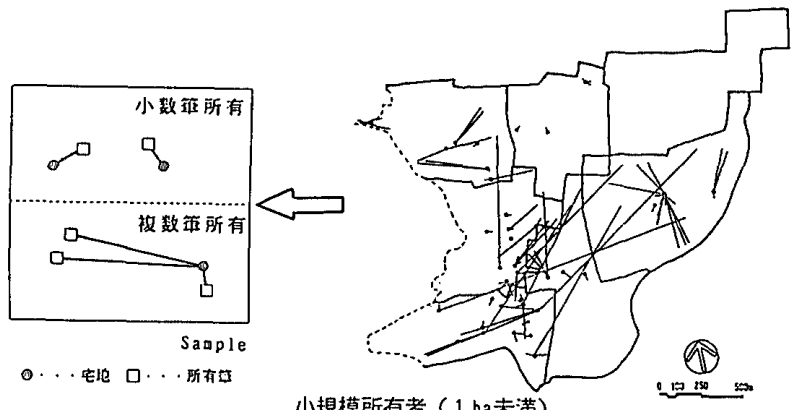

小規模所有者（1 ha未満）
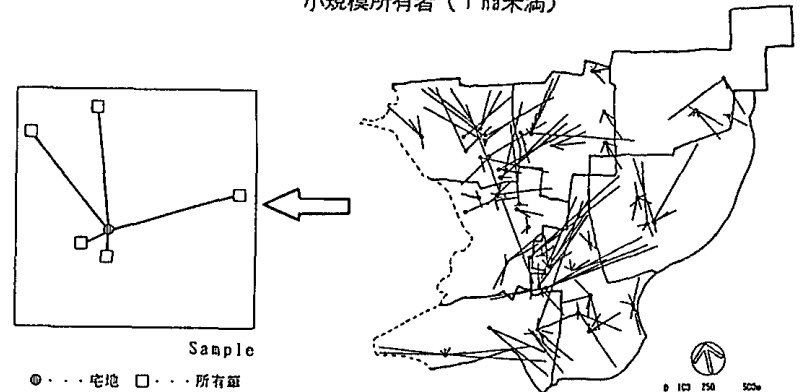

中規摸所有者 $(1 \sim 2 h a)$

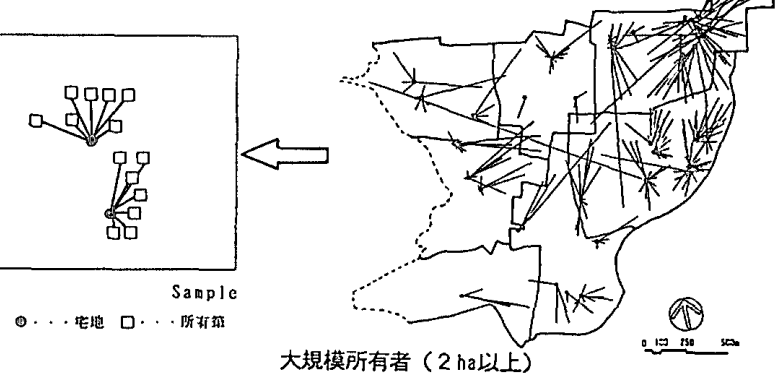

図11地区 4 の所有規模階層別の所有農地の箅分布

・中規模所有者については、自宅附近での所有が中心と なるが、大規模所有者については水田地域において確保 できない畑作地を距離が離れた地点に多く保有する所有 者がみられることが示される。

以上により、所有規模階層の相違功みた集落間土地 所有の圈域構造について、「集落内所有」、「地区内所 
有」、「旧村外所有」のそれぞれを軸とする農地所有者 の所有構造が示される一方、特に旧村外に所有地を持つ 所有規模階層としては、主として田では中規模所有者が、 畑では大規模所有者が該当することが明らかになった。

\section{4. 中心地区における筆単位の所有圈域構造とその形成 要件}

4 節では、土地所有による空間構造を連続する空間に

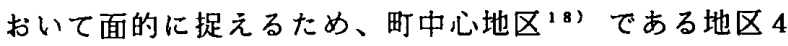
を事例に、筆単位による分析を行なった。

(1) 土地利用 (地目) と所有規模階層別の所有筆の分布

地区 4 は 7 つの集落より構成され、地区内の現況土地 利用は西部の丘陵地は山林として、東部の平地部は、宅 地、田を中心とした農地により構成される（図10）。集 落25〜27では宅地と小規模な田が混在して分布し、集落 28〜30においては、水田利用が中心となる。集落の地区 内での位置関係と土地利用内容から、集落25 27kつい ては中心集落、集落28～30kついては周辺集落と位置付 けられる。

地区内における所有規模階層別の所有筆分布をみると、 小規模所有者は中心集落に多く存在し、宅地の近くの筆 を小数所有する傾问が強いが、所有筆数が增えると集落 外への分散がみられるようになる（図11）。中規模所有 者は中心集落および中心集落に隣接する周辺集落（集落 28、30）に多く存在し、小規模所有者に比べて所有筆数 が増えるとともに、宅地の近くから集落境界を越える離 れた地点の筆を所有するという筆の分散傾问が強い。こ れに対し、大規模所有者は周辺集落に多く存在し、集落 属地内の比較的自宅加ら近い地点にまとまった筆を面的 に持つ傾向がある。

（2）集落別の居住宅地からみた所有農地の距離分布

次に、集落別に居住宅地と地区内の所有農地（田）の 距離について、居住宅地を原点に分布距離に対する累積 構成率 ${ }^{19}$ をみた（図12）。周辺集落である集落 $28 \cdot 29 \cdot 3$ 0.31においては居住宅地から距離の小さな地点までにお いて、その所有地の累積の度合いは大きくなり、ほぼ4 $00 \mathrm{~m}$ 程度の距離において累積面積の割合が $100 \%$ 近くに 達する。それに対し、中心集落である集落 $25 \cdot 26 \cdot 27$ にお いては、所有地は先ず、 $50 \mathrm{~m}$ 程度の居住宅地から地点ま では、周辺集落と同様に、累積面積の増加がみられるが、 それを越えると、その增加の傾きは緩くなり、面積の集 積度は低下する。中心集落のなかでも農業的土地利用の 大きな集落25については、累積面積が $100 \%$ になる距離 は小さいものの、集落27については、面積の集積が鈍く $100 \%$ となるのは $800 \mathrm{~m}$ を越える。つまり、非農業的土地 利用が大きい中心集落においては、農地を居住宅地周辺 に所有することが困難となり、小規模な農地であれば居 住宅地の近傍において所有できるが、ある程度以上の農
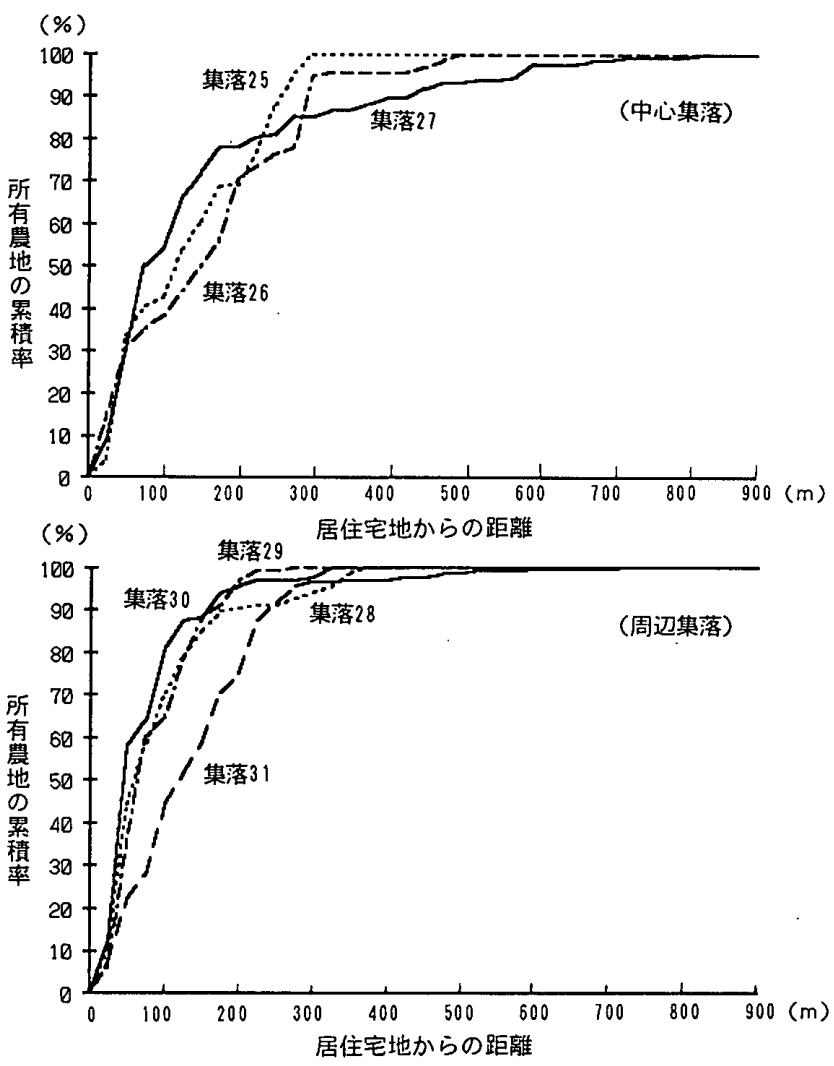

図 12 地区4の集落別の居住宅地からの距離による所有 農地の累積構成率

地を所有するためには、居住宅地から遠隔地に所有する という形態がみられる。それに対し、周辺部における体 落では、居住宅地から近い地点から、段階的に所有する ことが可能となるため、所有地のまとまりがみられるよ うになる。

5.まとめ

本研究では、平場から山場にかけて立地する $\mathrm{Y}$ 県 I 町 の2.300人の土地所有者が所有する約 79.000 筆の土地の 利用・所有内容を基に、農村地域の空間構造について土 地所有圈域の特質を明らかにしてきた。以下に本研究で 明らかになった点についてまとめる。

（1）集落群は土地所有上のまとまりを持ち、集落を基礎 的領域とした相互関連性により空間を構成する。そのま とまりの䇺囲は、集落一地区一旧村という社会領域と対 応した重層的構造をとり、集落・地区はそれぞれ土地利 用・所有における同質性と階層区分を持って旧村に組り 込まれ、集落一地区一旧村という利用・所有領域が現在 でも明確に存在している。

（2）集落間の土地所有関係では、地目について、畑や宅 地の所有は自集落を中心に隣接集落で収束し、田や山林 の所有は地区の範囲で収束するが、ほぼ旧村をその上限 とする領域性が存在している。また、集落立地条件につ いて、特に平場地域の田の土地所有に関して、散居形態 
をとる周辺集落では自集落の所有率が高くなるのに対し て、集居形態の中心集落および中心地区では自集落の所 有率が低く、その分、䇟接集落や地区内の周辺集落へ所 有が進出していることを集落の立地条件と土地所有構造 との関連性として示した。

（3）土地所有者の所有規模階層の相違では、大規模所有 者は自集落内を中心に農地を所有するのに对して、小規 模複数筆所有者や中規模所有者は集落境界を越えて分散 して土地を所有する結果、これらの所有構造が集落間関 係を規定すると同時に、土地利用を計画する上で計画主 体の構成に関する要件となることを示した。

（4）町中心地区の筆単位の分析では、大規模所有者は集 落内において農地を集約的に所有するのに対して、小規 模複数筆所有者や中規模所有者は、中心集落の宅地周囲 に小規模㖘地を所有する一方、集落外にも分散的に農地 を所有することが、面的な筆の位置分布と居住宅地から の距離分布による集計により示された。つまり、これら の分散小規模農地の集積化への誇導が土地利用計画上の 計画課題になっている。

以上により、農村地域の土地所有圈域は、社会領域に 対応した単位で形成し、旧村をほぼその限界に、集落。 地区のレベルでの結合力が強いことが明らかとなった。 すなわち、これらの社会領域、特に旧村という単位を計 画単位として再認識し、集落・地区・旧村の各地域単位 の性格を計画内容に取り入れること、ならびに、土地所 有分布においてキーパーソン的存在となる中規模所有階 層を計画に取り込むことが、土地利用計画における重要 な要件であることが求められた。

\section{注)}

1)藍澤宏、山下仁 : 農村地域における土地の利用域形成から みた土地利用計画に関する基礎的研究その1〜その3、日本 建築学会計画系論文報告集、第408号、PP81～92、1990.2、 第419号、PP69～78、1991.1、第426号、PP111 119.1991.8

2)「集落」: 農家が農業上相互に最す密接に共同し合ってい る農家集団として捉えられ、農業生産上形成されている最 小の地域単位である。一定の土地（地理的領域）と「家」 （社会的な領域）とを成立要件とした農村の地域社会であ る。集落境界を越えての耕地所有は出作・入り作といった 形で認識される。

「地区」：ここでは大字地区を指し、明治22〜23年まで村 であった圈域。明治期における町村制施行により、従来の 藩制村（いわゆる「ムラ」）が大字となった歴史的な経緯 をむつ。

「旧村」: 昭和29〜33年までの村であり、明治22年の町村 制施行により、地域的生活単位として団結できるような地 区（ムラ）を組合せたすのである。

3)研究対象地域の集落区分には、行政区、生産組合、農業集 落、国勢調査区などがあるが、ほぼ一致している。研究の 目的に合わせ、農業集落の区分を使用した。I町の農業集 落は、一般的な集落としての機能・実態を有している。
4) 今回の研究では、個人の土地所有データを使用しているた め、町名、旧村名などについては特に配虑し、匿名標記扱 いにしている。

5)ここでは 1 所有主体の意味として使用している。

6)現在の J R 線の下線用地

7)団体 : ここでは、複数人の個人主体と公共主体などの意味 として使用している。

8)中心地区 : 役場など、町の様々な中心的機能施設が集積し ている地区。I 町では旧村 A の地区 2 から旧村Aの地区 4 に、町の中心地区の位置が移っている。

9)平場・山場 : 山村振興法による旧村単位の区分によるもの。

10)集居・平場散居・山場散在 : 1970年の世界㖘林業センサス による集落形態区分。

11）企業：ここでは、公共主体を除いた複数人の個人主体の意 味として使用している。

12) $\mathrm{A}$ 集落による B 集落の土地所有率 $=「 \mathrm{~B}$ 集落内の $\mathrm{A}$ 集落内 居住者による所有面積の計(地目別)」／「A集落内居住者 による町内の総所有面積(地目別)」

13)共有林の扱いについて、町有林や国有林などの公共主体に よるものと集落など複数人の個人主体によるものがあるが、 居住集落単位の分析では、複数人による個人主体によるも ののみその居住集落による土地所有として扱っている。

14) $D i j=2 /(A i j+A j i) 、 D i j: i と j$ 距離、A $i j: i の j k$ おりる所有率(\%)で定義し、集落間所有率 $\mathrm{A} \mathrm{ij}+\mathrm{Aji}$ が 1 \%以下の場合は距離 D ijを 2.0 とし、距離の上限を設定し ている。距離Dijは、クラスター分析の計算過程で「クラ スター距離」として置き換わる。

15)距離D ijの設定式の計算から、クラスター距離 0.5 は地目 每に㧍ける集落間所有率の和が $4 \%$ 、クラスター距離 1.5 は所有率の和が約 1.3\%であることを表している。逆に所 有率の和が20\%である場合、クラスタ一距離は 0.1 となる。 この図では、縦軸の Oから 2.0 に问って集落間所有率の和 が小さくなり、集落間の所有における関係が小さくなる。

16)かつての中心地区、現在の位置に役場が建設される以前の 役場があった地区

17） $\mathrm{A}$ 集落の小規模所有者によるB集落の土地所有率 $=「 \mathrm{~B}$ 集 落内の A 集落内居住者 (小規模所有者のみ) による所有面 積の計(地目別)」/「A集落内居住者（小規模所有者のみ） による町内の総所有面積(地目別)」

18)町役場、町民センターが設置されている現在の中心地区

19)集落内に居住する所有者を対象として、その宅地から所有 農地までの距離と面積を基に算出したものである。

(1993 年 7 月 10 日原稿受理, 1993 年 12 月 27 日採用決定) 